\begin{tabular}{lllllll}
$\mathbf{C}$ & $\mathbf{A}$ & $\mathbf{N}$ & $\mathbf{O} \quad \mathbf{N}$ & $\mathbf{L}$ & $\mathbf{A}$ & $\mathbf{W}$ \\
\hline & & \\
& & \\
ROCZNIKI NAUK PRAWNYCH \\
Volume XXVIII, number 4 - 2018 \\
E n g l i s h v e r s i o n \\
DOI: http://dx.doi.org/10.18290/rnp.2018.28.4-8en
\end{tabular}

WIESŁAW BAR

\title{
FROM AN INCONVENIENT BISHOP TO THE INCOVENIENT DECISION TO RECOGNIZE HIM AS A MARTYR
}

On June 8, 2018, Pope Francis authorized the Congregation for the Causes of Saints to promulgate decrees recognizing the martyrdom of the Servants of God, Bishop Enrique Angelelli Carletti, diocesan priest $\mathrm{Fr}$ Gabriel Longueville, religious priest Carlos de Dios Murias (Franciscan, OFMConv), and Wenceslao Pederner, a husband and father, all murdered in Argentina during the so-called dirty war. ${ }^{1}$ The celebration of beatification will take place in La Rioja on 27 April 2019.

The earlier beatification of Archbishop O. Romero (2015) and his canonization on October 21, 2018-after a miracle had been acknowledged - provoked discussions in some circles concerning the changing of the concept of martyrdom by Pope Francis. ${ }^{2}$ Another impulse for further evaluation was the issuance of the decrees mentioned above. Are such claims justified? Are they true? To what extent do they correspond to the legal and factual state?

Due to the fact that the beatification cause concerns persons from a different continent and events that for many are distant in time, we will

Rev. WiesŁaw BAR, OFMConv, PhD, Hab, Full Professor, is the head of the Department of Canonization Law and Sacramental Law, Institute of Canon Law, Faculty of Law, Canon Law and Administration of the John Paul II Catholic University of Lublin (KUL); address: Racławickie 14, 20-950 Lublin, Poland; e-mail: wiesbar@interia.pl; https://orcid.org/0000-0002-8205-6678.

${ }^{1}$ M.D. Cоцомвo, "Reconocimiento del Martirio de Mons. Angelelli, los padres Murias y Longueville y el laico Wenceslao Pedernera," Circ. Nro. 24/2018 (June 8, 2018), accessed October 1, 2018, https://diocesisdelarioja.wordpress. wordpress.com/2018/06/08/1272; accessed October 11, 2018, http://press.vatican.va/content/salastampa/en/bollettino/pub blico/2018/06/09/180609a.html.

${ }^{2}$ See W. BAR, "Sprawy kanonizacyjne za pontyfikatu papieża Franciszka," in Prawo i praktyka kanonizacyjna za pontyfikatu papieża Franciszka, ed. L. Fiejdasz-Buczek (Lublin: Wydawnictwo KUL, 2018), 17-22 [in print]. 
first present the profiles of the martyrs (I), the course of the beatification processes (II), and then some objections will be put forward along with their evaluation in terms of the law and canonization practice (III).

\section{THE BEATIFIED MARTYRS OF THE DIOCESE OF LA RIOJA}

\section{BISHOP ENRIQUE ANGELELLI}

Enrique Angelelli Carletti was born in Córdoba (Argentina) on July 18, 1923 in the family of Italian immigrants Giovanni and Celina. ${ }^{3}$ Having completed his elementary education, at the age of 15 he began his tuition at the Seminario del Loreto, studying humanities and philosophy. Sent to Rome for further studies, he was ordained to the presbyterate on October 9, 1949. After obtaining his licentiate in canon law at the Pontifical Gregorian University, he returned to the diocese in the autumn of 1951, where he held the position of vicar in the parish of Alto Alberdi as well as working as a hospital chaplain. From 1952 onwards, he was committed to youth ministry (among others, he created Catholic youth movements: the JOC-Gioventù Operaia Cattolica and JUC-Gioventu Universitaria Cattolica), as an assistant to these organisations; he taught at a seminary and took increasingly bolder steps to reach out to people inhabiting areas of poverty—villas miserias.

On December 12, 1960, Pope John XXIII appointed him assistant bishop of the Diocese of Córdoba, where he carried out his ministry as we mentioned above. He participated in the last three sessions of the Second Vatican Council (1962-1965); during that time he started to support the Movement of Priests for the Third World (Il Movimiento dei Sacerdoti per il Terzo Mondo).

He was appointed diocesan bishop of La Rioja by Paul VI on July 11, 1968, and took possession of the office on August 24, the opening day of the Second Episcopal Conference of Latin America CELAM (Consejo Episcopal Latinoamericano) in Medellín, at which general support was expressed for sensitivity to social issues and for policy favouring the poor. ${ }^{4}$

\footnotetext{
${ }^{3}$ See IDEM, "O Biskupie niewygodnym dla rządzących," in Gaudium in litteris, ed. S.Janeczek, W. Bajor, and M. Maciołek (Lublin: Wydawnictwo KUL, 2009), 489-99; L.O. OLIBERTI and P.N. PAStrone, Enrique Angelelli, obispo de la Rioja: a imagen de Buen Pastor (Buenos Aires: Ed. Guadalupe Agape Libros, 2016), bibliography section, 97-103. The most comprehensive biography in L.M. Baronetto, Vida y Martirio de Mons. Angelelli Obispo de la Iglesia Católica, $2^{\text {nd }}$ ed. (Córdoba: Ed. Tiempo Latinoamericano), 2006.

${ }^{4}$ See the edition of the documents of the five conferences: Las Cinco Conferencias Generals del Episcopado Latinoamericano (Bogotá: CELAM, 2014), 956. Their presentation in Polish can
} 
Angelelli was the third bishop in the history of the Diocese of La Rioja (Dioecesis Rioiensis), founded on April 20, 1934 by Pius XI's bull Nobilis Argentinae nationis Ecclesiae, covering the entire territory of the province of La Rioja. ${ }^{5}$ Getting to know the living and working conditions of the faithful, he focused on educating them "towards freedom." He remained close to the workers and peasants, visiting them, promoting the idea of cooperatives in opposition to their being exploited by the richest and "powerful" in the region. He condemned usury, drug trafficking and gambling houses that profited from organised prostitution. ${ }^{6}$ As a result, he brought upon himself the wrath of the wealthiest who instigated merchants and landowners against the bishop. On June 13, 1973, he was even thrown stones at while he celebrated Mass on a feast day in Anillaco. He continued to work for the poor, explaining that he could not abandon it because God did not want men and women to be resigned but to "peacefully fight for freedom, and not end up in new slavery." The radio boycotted the transmission of his Mass from the cathedral. ${ }^{7}$ The bishop made the following comment: "Even if they force us to remain silent, Christ speaks out," adding: "No page of the Gospel commands to be stupid, to have eyes closed or ears plugged." 8

be found in J. TOMASZEWSKI, "Konferencja Episkopatów Ameryki Łacińskiej, Las Cinco Conferencias Generales del Episcopado Latinoamericano," Roczniki Teologi Katolickiej 14, no. 2 (2015): 171-74 (collection review); and A. PIETRZAK, Opcja na rzecz ubogich znakiem wiarygodności Kościoła (Pieniężno: Referat Misyjny Seminarium Duchownego Werbistów, 2002).

${ }^{5}$ This was done when the Diocese of Córdoba was elevated to the rank of a metropolis, which came to include the new diocese of La Rioja. PIUs EPISCOPUS, De nova erectione et cumscriptione dioecesium provinciarumque ecclesiasticarum in Republica Argentina Nobilis Argentinae nationis Ecclesia, April 20, 1934, AAS 27 (1935), 258-61. Decree No. 45.984 of 24 July 1934; the act authorising its creation: Act No. 11.715, Buenos Aires, September 20, 1933. Boletín Oficial, April 5, 1934; accessed October 1, 2018, http://www.saij.gob.ar/11715-nacional-creacion-diocesis-lns0002516-1933-09-20/1234193456789-0abc-defg-g61-52000scanyel.

${ }^{6}$ On the general situation in the Province (including the political one), see: P. NAZARENO Pastrone, Mons. Enrique Angelelli, testigo de la Fe, Revista Teología 42, no. 118 (2015): 53-54.

${ }^{7}$ They were published on the $10^{\text {th }}$ anniversary of the Bishop's death: Pastor y Profeta. Mensajes de Monseñor Angelelli (Buenos Aires: Ed. Claretiana, 1986). The new edition was prepared by Editorial Tiempo Latinoamericano: Misas Radiales Mons. Angelelli, foreword by Leonardo Boff, vol. 1, Año 1968-69-70; Misas Radiales Mons. Angelelli II, foreword by Bp Pedro Casaldáliga, vol. 2, Año 1971 (Córdoba, 1998); Misas Radiales Mons. Angelelli III. Homilías radiales del los años 1072/73, vol. 3 (Córdoba, 2012); Misas Radiales Mons. Angelelli, Homilías radiales del los años 1974-1975-1976, vol. 4 (Córdoba, 2012). The preserved recordings were made available by the Diocese of La Rioja in 2015: "Homilías radiales de Mons. Angelelli," accessed October 10, 2018, www.diocesisdelarioja/wordpress.com.

${ }^{8}$ Nazareno Pastrone, Mons. Enrique Angelelli, testigo de la Fe, 55. 
Denunciations sent to the Holy See resulted in Pope Paul VI sending a visitator. Archbishop Vicente Zaspe, appointed for the task, said: “Angelelli is neither a communist nor a Marxist, but a Catholic bishop in full communion with the Pope," adding that the ministry of the local Church is in harmony with the pastoral ministry of the Universal Church, which wants to continue this work by implementing the decisions of the Second Vatican Council, those of Medellin (CELAM 1968) and San Miguel (1969) to "be in the service of the poor." 9

During his ad limina visit in 1974, the bishop was advised to remain in Rome because his return to Argentina posed a risk. However, he did not consider that as an option. The situation changed after the coup d'état of March 24, 1976. He would send reports after priests and religious were detained. However, seeing attempts to destroy the unity of bishops, he wrote a letter to Archbishop Zaspe on April 26 using his own example, making himself available to the Church and expressing his willingness to renounce from the common good if the continuation of his mission were to "give the Holy See a headache, or to the nuncio or fellow bishops." 10

However, he did not leave the diocese even when Fr Carlos de Dios Murias and Fr Gabriel Longueville had murdered in his diocese. When he tried to investigate the circumstances surrounding their deaths, he heard these words from General Luciano Benjamín Menéndez: "Your Excellency must be very careful." Soon afterwards, on August 4, the bishop was killed in Punta de Los Llanos.

After a provoked road accident, the documents concerning his inquiry into the murder of the two priests vanished from the car. Earlier, the bishop had sent a copy of the documents concerning the crimes committed by the military junta to the Holy See. This copy, with the permission of Pope Francis, was used in the 2014 criminal trial of the perpetrators, in which Bp Marcelo Daniel Colombo - the governor of the Diocese of La Rioja at the time-was the auxiliary prosecutor.

It was not until July 4, 2014 that the La Rioja City Court sentenced the general and Luis Estrella to life imprisonment for organising and ordering the murder of Bishop Angelelli, who was considered to be the enemy of the dictatorship of Jorge Raphael Videla. ${ }^{11}$

\footnotetext{
${ }^{9}$ Ibid., 56 .

${ }^{10}$ Ibid., 58

11 "To nie był dziwny wypadek. Wyroki za zamordowanie bpa Angelellego," accessed October 1, 2018, www. osservatoreromano.va/pl/new/nie-byl-dziwny-wypadek. Find the text of the
} 


\section{THE MARTYRS OF CHAMICAL}

Carlos de Dios Murias was born in San Carlos Minas, in Córdoba Province, on October 10,1945, in the family of a teacher and a real estate agent and provincial politician. The father saw his only son (Carlos had three sisters) in the military, so he took up education in a military high school. However, after the secondary school, Carlos took up studies of veterinary medicine and then civil engineering. Having abandoned them, he worked at a property register office, engaging in the activities of Christian youth workers (JOC), with the assistant Fr Angelelli, whom he met while at high school.

In 1965, Carlos met some Franciscans during one of the conventions of the Fokolari Movement and decided to join the Order of Friars Minor Conventual. After his novitiate in 1966, he took his first religious vows, and after completing his philosophical and theological studies, he was ordained a priest (December 12, 1972) by Bishop Enrique Angelelli at Murias' request, who valued the bishop for his work with the poor. In fact, he followed a similar path, first working at the minor seminary in Moreno and then in the toughest places of the Franciscan parish of José León Suárez (Gran Buenos Aires). "There, he sowed a seed that later sprouted among a group of young people, in whom he ingrained Christian commitment together with the evangelical option for the poor and the most needy in search of new paths that would lead to a more equitable society."12 Finally, he asked for permission to work in the diocese of La Rioja, which was then headed by Bishop Angelelli. Having obtained the approval of the Provincial Custodian, Fr Jorge Morosinotto, he came to his diocese in 1975. He was appointed parochial vicar in the village of Chamical, in the area of Los Llanos Riojanos, where Fr Gabriel Longueville was the pastor. ${ }^{13}$ The inhabitants were agricultural workers, and just as elsewhere in the diocese about $90 \%$ of them lived in poverty. After the military coup d'état in March 1976, pressure started and Fr Carlos became the object of threats, to which he responded in one of his last homilies: "They can silence this priest. They

228 pages long judgement in Federal Oral COURT of LA Rioja, NATiOnAl Judicial Branch, case no. 97000411/2012, "Causa lesa humanidad «Monseñor Angelelli»," accessed October 1, 2018, www.cij.gov.ar/nota-14019-Lesa-humanidad-difunden-fallo-que-conden-a-los-dos-acusados-enel-juicio-por-el-homicidio-del-obispo-Angelelli.html.

${ }^{12}$ H.S. LuPPI, "Un futuro santo y su paso en las villas de J.L. Suárez," acccessed October 1, 2018, http://villasweb.org/ 2016/02/24/un-futuro-santo-y-su-paso-en-las-villas-de-j-1-suarez.

${ }^{13}$ G. ZANIN, "XXII Aniversario de la muerte de fray Carlos De Dios Murias," accessed October 11, 2018, www.ofmconv.org/x/Murias-sp.htm. 
can silence the bishop's voice, but they will never be able to silence the voice of the Gospel." 14

Gabriel Longueville was born on March 18, 1931, in a rural settlement of Etables Ardẻche, within the limits of the French diocese of Viviers. He was admitted to a lower seminary in 1942 and a higher seminary in 1948. Ordained a priest on July 23, 1957, he taught the language at the lower seminary, but still wanted to preach the Gospel beyond the borders. When he received permission, he went to Mexico to prepare for his ministry, and in 1970 he arrived in Argentina, in Corrientes. In March 1971, he was incardinated to the diocese, and in 1972 Bishop Angelelli appointed him pastor at Chamical. He would travel across the parish, meeting people and writing about them to his family and friends like this: "The living conditions of the most are wretched; their salaries are a third of those in Buenos Aires, people have no secure jobs. Really, one does not know where the families get their livelihood from [...] Unfortunately, the rubbish lying around is a breeding ground for flies. There's an epidemic of abandoned families in the neighbourhood. We have organized groups to get clothes and distribute them among those in need of them." ${ }^{.15}$ From 1975, he had a co-worker, Fr Carlos de Dios Murias, with whom they jointly put Bishop Enrique's pastoral programme in practice: in the spirit of service and collaboration, in accordance with the teachings of the Second Vatican Council, taking into account the socio-religious reality of the local population, in order to promote integral development of humans. ${ }^{16}$

On Sunday, July 18, 1976, after evening Mass, Fr Carlos Murias and Fr Gabriel were having dinner at the house of the Sisters of Saint Joseph, who carried out their ministry in the parish of the Saviour in Chamical. There came two civilians who introduced themselves as federal policemen. They summoned Fr Carlos to see the provincial authorities. Fr Gabriel did not want to leave him alone, so he cried "I'm coming with you!"17 Both were taken to the military base in Chamical, where they were tortured and probably murdered. ${ }^{18}$ It was not until Tuesday, July 20 , that some railway

\footnotetext{
${ }^{14}$ D.A. Rehin, Memoria de un Testigo: testimonio de la vida de fray Carlos de Dios Murias (Buenos Aires: Misiones Franciscanas Conventuales, 2005), 160.

15 "Gabriel Longueville," accessed October 1, 2018, http://diocesisdelarioja.files.wordpress. com/2016/07/04-gabriel-lonfueville.pdf, p. 1.

${ }^{16}$ Nazareno Pastrone, Mons. Enrique Angelelli, testigo de la fe, 52-53.

${ }^{17}$ Ibid., 2.

${ }^{18}$ National Commission on the Disappearance of Persons, Nunca más. Informe... (Buenos Aires: Eudeba, 1984), 472.
} 
workers came across their bodies near the railway tracks, about $5 \mathrm{~km}$ south of Chamical, riddled with bullets, joined by handcuffs, and bearing traces of torture. During the funeral homily on July 22, Bishop Angelelli addressed the perpetrators, offering them forgiveness for "this is what the Gospel says: forgive!" asking God to soften their hearts so that they might turn to God, be his good children and good brothers to their neighbors. ${ }^{19}$ The military did not allow the mass media to report on the funeral and the bishop's message to the faithful in connection with the death of the priests.

\section{WENCESLAO PEDERNERA}

On July 25, 1976, in Sañogasta, Wenceslao Pederner was wounded six times by a group of four hooded individuals, in his own home, at 2.45 a.m., in front of his wife and three children. He died at 3 p.m. on that day in the Chilecito hospital, having received the sacraments and forgiven the perpetrators. ${ }^{20}$

Wenceslao was born on September 28, 1936, in Los Jagùeles, in the province of San Luis. He studied and worked, and at the age of 16 he came to Mendoza to work in a vineyard. In June 1961, he met his future wife (Martha Ramona Cornejo), daughter of the vineyard manager, and despite his opposition the young people were married on March 24, 1962 in the Church of Saint Isidore the Labourer in Rivadavia. As his wife testified, Wenceslao was not religious, so he did not want a church wedding. However, after a few days he showed such readiness, and when a church had been built in the vineyard, under the influence of the Bible he changed his attitude towards church institutions as well. In 1968, he participated in parish missions, and together with his wife they were elected leaders of the group of families gathering to reflect on the Holy Bible. He became a catechist. This change was also supported by the newly met Carlos di Marco and Rafael Sifré, who were acquaintances of Bishop Angelelli. They encouraged Wenceslao to come to La Rioja because there was a shortage of people working for the Church to help the needy. He had already been chosen as a trade unionist who would represent the position of agricultural workers and joined the rural movement of Catholic Action.

\footnotetext{
${ }^{19}$ E. ANGELELLI, "Homilía con motivo del entierro de los sacerdotes Gabriel Longueville y Carlos Murias," Pastor y Profeta (Buenos Aires: Claretiana, 1986), 132.

${ }^{20}$ For Fr Gonzalo Llorente's testimony, see http://martiresargentinos.blogspot.com/2012/07/ wenceslao-pedernera-laico.html [accessed October 1, 2018].
} 
In June 1973, he and his family arrived in the vicinity of the provincial capital, Anguinán, and then in Sañogasta, where they bought some land and set up a work cooperative, combining it with the promotion of life in faith. Still engaged in the rural movement of Catholic Action, they moved to the parish of Nuestra Señora de la Candelaria de Sañogasta. Then he became an object of intimidation, threats and warnings, and finally gave his life for "ideals and simplicity of life of service." 21

\section{BEATIFICATION CAUSES AND PROCESSES}

According to the Minister Provincial of the Franciscans of Argentina and Uruguay, Fr Carlos Trovarelli, Cardinal. J.M. Bergoglio approved the institution of the cause of Fr Carlos de Dios Murias "with discretion" in order to prevent Argentinian bishops from blocking such initiatives with regard to priests involved in social affairs in the $1970 \mathrm{s.}^{22}$ The fact remains, however, that the opinion of the martyrdom had spread throughout the diocese and among the Friars Minor Conventual. Bishop Bernardo Witte of the Diocese of La Rioja decided to begin preparations for the beatification process of all four martyrs by appointing a special commission on June 22, 1990, which would gather all possible documentation of the events of July and August $1976 .^{23}$ However, his successor Bishop Fabriciano Sigampa suspended the works. Indeed, Cardinal Bergoglio delivered a homily at La Rioja Cathedral on the $30^{\text {th }}$ anniversary of the death of Bishop Angelella, in which he spoke of the pastoral dialogue which he had experienced personally with the people of La Rioja - "dialogue with the increasingly persecuted Church, the Church marked by Wenceslao's blood, Gabriel and Carlos [...], and the blood of

\footnotetext{
${ }^{21}$ The words of Bishop Colombo at the anniversary celebrations in Sañogasta can be found in G. CARrizo, "Recordan al laico Wenceslao Perdernera en Sañogasta," El Diario Chilecito, July 27, 2015, p. 1; see J.J. Gravet, "Martires de la Iglesia en Argentina. Wenceslao Pedernera (39 años)," accessed October 10, 2018, http:// martiresargentinos.blogspot.com/2012/07/wenceslaopedernera-laico.html; "Quién fue el laico asesinado en Sañogasta que el Vaticano analiza canonizar," accessed October 12, 2018, http://www.elfederalonline. com/2017/03/09/quien-fue-el-laicoasesinado-en-sanogasta-que-el-vaticano-analiza-canonizar.

22 "Papa quiere canonizar a seis religiosos argentinos asesinados por militares," accessed September 7, 2018, www.elobservador. com.uy/nota/papa-/quiere-canonizar-a-seis-religiosos-argentinos-asesinados-por-militares.

${ }^{23}$ C.M. ZAMBELLI, "Relazione del postulatore generale," accessed October 1, 2018, http://www.ofmconv.org/capgen01/reg-Postulator-IT.htm.
} 
a shepherd who was a witness to the faith." ${ }^{24}$ However, it was only four years later, on 19 July 2010, that the new bishop of La Rioja, Roberto Rodríguez, announced his intention to commence the beatification process of the "martyrs of Chamical," as they were commonly called. The case of Wenceslao Pedernera, the lay catechist who was engaged in Catholic Action, was later appended to the process. Pedernera was murdered on July 25, 1976, a week after the priests.

The process was introduced by the Diocese of La Rioja, with Postulator General of the Order of Friars Minor Conventual Damian Gheorghe Patrașcu, and Vice Postulator Martín Bitzer in the area of the diocese. The inauguration of the process (opening session) in the diocese took place on May 31, 2011. In June, Mass was celebrated at the Church of the Saviour (El Salvador) in Chamical, where the priests exercised their ministry. The Mass was celebrated by Fr José Luis Genaro, in the presence of Diocesan Bishop Robert Rodríguez. The Congregation for the Causes of Saints issued its nihil obstat on July 24, 2011. After four years, on 15 May 2015-the diocesan proceedings were closed.

The diocesan phase of the beatification process of Bishop Enrique Angelelli did not start until October 13, 2015 and ended on September 15, 2016. ${ }^{25}$ Earlier, the Congregation for the Causes of Saints issued a decree nihil obstat-on April 21, 2015. During the stage in Rome, the two beatification causes were merged. After the Positio super martyrio was compiled, the publication was evaluated by the ordinary congress of theologians (May 15, 2018), and on June 8, 2018, Pope Francis authorized the Congregation to issue a decree on martyrdom.

The expert on the beatification process of Enrique, Luis Liberti, in an interview for Vatican Insider ${ }^{26}$ stated that all three priests were victims of the same political process. The witnesses to conversations with Bishop Angelelli, testify that after the deaths of the Franciscan and Fr Gabriel the Bishop was convinced that a spiral process had started, which would lead to "copete

\footnotetext{
24 "Homilía del Cardenal Mons. Jorge M. Bergoglio en ocasión del 30 Aniversario del fallecimiento de Mons. Enrique Angelelli-Catedra de La Rioja," accessed October 20, 2018, www.arzbaires.org.ar/inicio/homiliasbergoglio.html.

${ }^{25}$ M.D. Colombo, "Conclusión de la instrucción diocesana de la causa de canonización de Mons. Angelelli,” Circ. Nro. 36/2016, accessed October 1, 2018, https://diocesisdelarioja.word press.com/2016/09/07/conclusion-de-la-instruccion-diocesana-de-la-causa-de-canonizacion-de-monsangelelli.

26 "A la Iglesia argentina le falta verbalizar la dictatura," accessed September 7, 2018, www.lastampa.it/2017/03/08/vaticaninsider/a-la-glesia-argentina-le-falta-verbalizar-la-dictatura.
} 
rojo," thinking of himself. On the day when the inquiry into the deaths of the Chamical priests was completed, Angelelli was killed. Both historical and sociological research shows that the province of La Rioja came under the heaviest persecution: whoever had any ties with Angelelli, was detained, imprisoned or murdered. The referenced author believes that 40 years after this death, the Church in Argentina still has not addressed many issues from the period of the military dictatorship. Thanks to the beatification process, a lot of those matters are now discussed more openly, such as those related to the Diocese of La Rioja.

\section{ON MARTYRS INCONVENIENT TO...?}

Ten years ago, I wrote an article On the Bishop inconvenient to those in power $^{27}$ — both to those governing the State and the Church in Argentina. In the first case, the democratic elections of December 10, 1983 were significant, although secret files from the dictatorship era were not revealed until 2013, and the sentence in the first instance trial of those accused of causing the death of Bishop Angelella of 1986 was not effective due to the amnesty which was repealed as late as in 2005. In the second case, it was only then that a significant change occurred, prompted by the first participation of the delegation of the Conference of Bishops, headed by Cardinal Bergoglio on the occasion of the 30th anniversary of the death of Bishop Enrique (2006). However, the change has not been backed by all church circles and by all believers, as evidenced by reactions to Pope Francis' decision to acknowledge the martyrdom of the Bishop and his collaborators. Their beatification is still inconvenient to some.

Vicente Montesinos, while asking if there is anyone who can explain the beatification of Bishop Enrique Angelelli to him, ${ }^{28}$ states directly that being beatified or canonized during this pontificate is becoming a "high risk" state if we see this case in the light of so many saints or role models whose elevation to the altars was preceded by meticulous studies. While endorsing the opinions of six witnesses who testified that the Bishop died in a road accident rather than as a martyr who gave his life for the Gospel, he considers

\footnotetext{
${ }^{27}$ See Footnote 3.

${ }^{28}$ V. MONTESINOS, “¿Puede alguien explicarme la beatificación de Monseñor Enrique Angelleli?” accessed September 7, 2018, http://infovaticana.com/blogs/adoracion-y-liberacion/puede-alguienexplicarme-la-beatificacion-de-monsenor-enrique-angelelli.
} 
Francis' decision to be one of the pillars of a creeping revolution intended to introduce Marxism to the Argentinian Church using the poor. He further believes that the Bishop's preaching served to incite a disturbance, which resulted in increased violence, and the Bishop's name would be ironically changed in La Rioja from Angelelli to Satanelli... The referenced author believes that by his decision to recognize the deaths of Bishop Angelelli and his three collaborators as cases of martyrdom, Pope Francis broadened the concept of odium fidei to include the political attitudes of the victims. Not questioning everything in the life of this group, he points to a more appropriate path for the heroic virtue processes, both of the Bishop and the Companions.

First of all, it should be noted that as soon as Pope Francis commenced his pontificate, many stressed that he was open to changes in both doctrine and practice. ${ }^{29}$ Examples of this can also be clearly seen in canonization causes. To this end, Francis has implemented several new regulations in this area. ${ }^{30}$ While the norms concerning the financing of processes, as well as the rules of the Medical Board concerning the authenticity and preservation of relics are to ensure transparency and effectiveness of the proceedings as well as veneration of saints which would be free of abuse, the identification of a third measure of canonized holiness, apart from martyrdom and heroic virtues, has a constitutive importance. The apostolic letter issued motu proprio Maiorem hac dilectionem was published by Pope Francis on July 11, $2017^{31}$ — a fact overlooked by Montesinos — ultimately mitigating the standpoint and proposing a path of heroic virtues. The Pope distinguished a third path to canonized holiness: a voluntary and sincere offer of life for others

\footnotetext{
${ }^{29}$ See, for example, a comparative study in S. MAGISTER, "El paso doble del Papa argentino," accessed August 1, 2017, http://chiesa.espresso.repubblica.it/articolo/1351008.

${ }^{30}$ Congregation for the CAuses OF SAINTS, Norms Regarding the Administration of Temporal Goods in the Causes of Beatification and Canonization, March 10, 2016, AAS 108 (2016), 495-98; English translation available on http://www.vatican.va/roman_curia/congregations /csaints/documents/rc_con_csaints_doc_20160307_norme-beni-cause_en.html; IDEM, Regulation of the Medical Board of the Congregation for the Causes of Saints, September 23, 2016, AAS 108 (2016): 1004-9; English translation available on https://press.vatican.va/content/salastampa/ en/bollettino/pubblico/2016/09/23/160923a.html. IDEM, Las reliquias en la Iglesia: autenticidad y conservación, accessed October 10, 2018, http://www.causesanti.va/content/causadeisanti/ it/documenti/le-reliquie-nella-chiesaes.html.

${ }^{31}$ FrANCIS, Lettera apostolica in forma di Motu Proprio del Sommo Pontefice Francesco Maiorem hac dilectionem sull'offerta della vita [Apostolic Letter Issued Motu Proprio "Maiorem hac dilectionem" on the Offer of Life], Bollettino, July 11, 2017, http://press.vatican.va/content/ salastampa/it/bollettino/pubblico/ 2017/ 07/11/0484/01075.html; English translation available on https://press.vatican.va/content/salastampa/en/bollettino/pubblico /2017/07/11/170711a.html.
} 
and the perseverance in this decision until death. The Secretary of the Congregation for the Causes of Saints warned that none of the dispositions of this letter violates the Catholic Church's doctrine on Christian holiness leading to beatification or the traditional procedure. ${ }^{32}$ In connection with the above mentioned objection, in the context of Maior hac dilection, it should be stated that if the processes of the La Rioja martyrs had started after July 11,2017 , it would now be easier to conduct them because the martyrs gave their lives to save others voluntarily. Adhering to the traditional formula of attaining canonized holiness — "virtues" and "martyrdom"- those martyrdom cases were dealt with only after a explicit court decision affirming that Bishop Angelelli did not die in an accident but was murdered.

According to the biblical theologian Eduardo de la Serna, one of the leaders of the group of priests in the so-called option for the poor, the decision of Pope Francis - like the previous one with regard to Archbishop Romeroclearly broadens the understanding of odium fidei. Hate of faith was previously taken into consideration in justifying the martyrdom of victims of communism or ethno-cultural conflicts, but not those "murdered by Latin American dictatorships - western and Christian." Nowadays, this recognition "means that the struggle for justice, the dignity of the poor and human rights is a constitutive element of the Christian faith;" it is to galvanise believers into action by holding out examples of people who died in their service. ${ }^{33}$

The above text sounds almost grotesque in light of the teaching of Pope Benedict XIV, who wrote as early as in the eighteenth century: "Not only a pagan or an infidel but also a wicked Christian can be a persecutor or tyrant." He gave examples of the Polish king Bolesław the Bold (the assassin of Bishop Stanislaus), the king of England Henry (the Thomas Becket case), or Wenceslaus IV of Bohemia (who had John of Nepomuk killed), "all of whom were Catholics," and the deaths they ordered were inflicted "out of hatred for the noble attitude (i.e. virtue), which involves the practice of faith." ${ }^{34}$

\footnotetext{
${ }^{32}$ M. BARTOLUCCI, "La quarta via. Una nuova fattispecie nell'iter processuale delle canonizzazioni." L'Osservatore Romano, July 11, 2017, accessed October 1, 2017, www.osservatore romano.va/it/news/la-quarta.

33 "En el camino de la declaración de santidad," accessed October 1, 2018, www.pagina12. com.ar/120366-en-el-camino-de-santidad.

${ }^{34}$ BENEDICT XIV, De Servorum Dei beatificatione et Beatorum canonizatione (Prati 1840), XIII, 3 , vol. 3, p. 114; see W. BAR, Sendero Luminoso_prześladowca (Lublin: Redakcja Wydawnictw KUL, 1999), 54-55.
} 
The repeated allegation that the concept of odium fidei has been broadened to include the political attitude of the victims as well as the argumentation are unjustified because in odium fidei does not have to concern only the truths of faith, but also the good works resulting therefrom, a conclusion which is elaborated by Pope Benedict XIV, who used the examples of causes taken from the history of the Church. He teaches that defence of the Christian virtue, rejection of sin, being just, that is, doing good, is as a matter of fact a profession of faith, and the resultant death is martyrdom. ${ }^{35}$ Furthermore, it should be noted that the Fathers of the Church and Christian writers placed witnesses of faith and their testimony to the love of faith-de amore fidei-at the core of their deliberations. ${ }^{36}$ Critics of the papal decision almost completely disregard this subject; for many, the decision is still difficult to accept because of the necessity of facing their own consciences, and this is why it is inconvenient.

Finally, it should be pointed out that Francis emphasizes other aspects of the spirituality of the saints, or rather calls them differently than his predecessors did. A clear example of this can be found in the canonization of Mother Teresa. For John Paul II, she was a person carrying a message for our times, and was a frequent theme of his pontificate in the context of "the civilization of love" or "respect for life." For Francis, it is very important to reach out to people who are marginalised on the peripheries of human existence, to the poorest among the poor. ${ }^{37}$ The same was true of the activities of Bishop Enrique, Carlos, Gabriel and Wenceslao, and now it is important to evaluate their deaths as martyrs.

Occasionally, objections are formulated out of "concern" for a cause. Here is the opinion of the editorial staff of La Nacion: "The rigour with which the beatification processes are conducted is well known [...]. In this case, there is no such thing," a commentator argues. ${ }^{38}$ At the same time, these same media, on the day when Pope Francis embarked on his pontificate (March 19, 2013), were spreading the news that Carlos de Dios Murias, one of the martyrs of Chamical, would be the first blessed during the era of

\footnotetext{
${ }^{35}$ Benedict XIV, De Servorum Dei, vol. 3, 18.3-4 and 8.

${ }^{36}$ W. BAR Sprawy kanonizacyjne Męczenników XX wieku. Studium nad jurysprudencją Kongregacji (Lublin: Wydawnictwo KUL, 2003).

${ }^{37}$ See FRANCIS, "Niestrudzona pracownica miłosierdzia. Homilia," L'Osservatore Romano, Polish ed. 9 (2016): 9-10.

38 "Una beatificación de tono político-ideológico," accessed September 7, 2018, www.lanacion. com.ar/2157470-una-beatificacion-de-tono-politico-ideologico.
} 
Pope Francis. ${ }^{39}$ When the latter made his decision five years later, preceded by the necessary processes and studies, there was an outcry that it was unjustified. This was denied by Bishop Marcelo Daniel Colombo, in a circular letter to the faithful, and the Episcopate of Argentina accepted his vote as his own. ${ }^{40}$ Earlier, the bishop had given an interview in which he underscored the present pope's good knowledge of the case. He also mentioned that the young Jorge Bergoglio assisted the Jesuit general (Fr Pedro Arrupe) during his visit to Famatina in the Diocese of Rioja. This was when he also encountered Bishop Enrique, who was delivering a conference for a group of Jesuit superiors from Latin America. Later, as Provincial, he visited the religious houses in La Rioja, meeting again with the ordinary of the place. ${ }^{41}$ On May 20, 1992, he was appointed auxiliary bishop to the metropolitan bishop of Buenos Aires. From June 1997, he was the archbishop coadjutor of Cardinal Antonio Quarracino, and after his death he took office in the metropolis on February 28, 1998. In the same year (in November), he became the ordinary for the faithful of the Eastern rites. In February 2001, he received a cardinal's hat. He was Vice-President of the Argentine Episcopal Conference and then President for two terms (2005-2011).

Indeed, he took some time to make decisions regarding canonization causes. First, as the Metropolitan of Buenos Aires, Jorge Bergoglio agreed to launch a process of martyrs from the period of the recent military dictatorship (1976-1983). The first proceedings were opened on August 8, 2005 and concerned five Pallottines murdered in Villa Urquiza (Belgrano) on July 4, 1976, four of them Argentinian and one Spanish. The petitioner in this case was the Parish of Saint Patrick in which they worked. According to the available data, the cause still has not record number assigned or the nihil obstat of the Congregation for the Causes of Saints.

39 “El primer de beato de la 'era Francisco' podría ser un cura asesinado por la dictadura argentina," accessed October 1, 2018, https://www.periodistadigital.com/religion/america/2013/ 03/19/elprimer-beato-de-la-era-francisco-podria-ser-un-cura-asesinado-por-la-dictadura-argentina.shtml.

${ }^{40}$ M.D. Colombo, Consideraciones sobre manifestaciones periodísticas agraviantes, Circ. Nro. 31/2018, accessed October 21, 2018, http://www.episcopado.org/contenidos.php?id=1766 \&tipo=unica.

${ }^{41}$ A. Beltramo Álvarez, "Más cerca de la beatificación: 'Angelelli es nuestro',” La Stampa, May 16, 2018, accessed September 7, 2018, www.lastampa.it/2018/05/16/vaticaninsider/ mscerca-de-la-beatificacion-angelelli-es-nuestro; see N. SCAVo, "Braccato dai lupi per le vie di Buenos Aires. L'incontro tra Bergoglio e il vescovo di La Rioja negli anni della dittatura" (October 14, 2014), accessed October 1, 2018, www.osservatoreromano.va/it/news/ braccato-dai-lupile-vie-di-baires. 
On the other hand, it is unjustifiable to assign Cardinal Bergoglio any particular credit with regard to the commencement of the process of the Chamical martyrs. As indicated in Section II, the diocese did make attempts; and the diocese formally opened the case. Notwithstanding, Cardinal Bergoglio signed the opinion of the Argentine Episcopal Conference on the commencement of this procedure, as required by canonization law, but in this case he acted as its President. ${ }^{42}$

\section{CONCLUSION}

On the occasion of the upcoming beatification, the bishops of Argentina, gathered at the 180th plenary meeting (August 21-23, 2018), sent a letter to the administrator of the Diocese of La Rioja, Fr Roberto Enrique Queirolo, containing these words: "Today we need those models of people who know how to do their utmost in the struggle for the rights of the weakest, being able to promote communion and peace at the same time." ${ }^{, 43}$ It is to be hoped that just as the beatification process led to greater openness in the discussion of many issues in the history of the State and the Church, the beatification of the Martyrs of the Diocese of La Rioja will help to clear the memory and conscience of people, for a life in the desirable "communion and peace."

\section{BIBLIOGRAPHY}

\section{SOURCES OF LAW}

Benedictus PP. XIV. De Servorum Dei beatificatione et Beatorum canonizatione. Vol. 3. Prati 1840.

PIUS EPISCOPUS. De nova erectione et cumscriptione dioecesium provinciarumque ecclesiasticarum in Republica Argentina Nobilis Argentinae nationis Ecclesia, April 20, 1934. AAS 27 (1935), 257-63.

Francis. Lettera apostolica in forma di Motu Proprio del Sommo Pontefice Francesco Maiorem hac dilectionem sull'offerta della vita [Apostolic Letter Issued Motu Proprio "Maiorem hac dilectionem" on the Offer of Life]. Bollettino, July 11, 2017, no. B0484. English translation

\footnotetext{
${ }^{42}$ See the relevant regulations: CONGREgation fOR THE CAUSES OF SAINTS, Norms to be observed in inquiries made by bishops in the causes of saints, February 7, 1983, AAS 75 (1983), pars. I, 396-403, no. 11a; IDEM, Sanctorum Mater. Instruction For Conducting Diocesan or Eparchial Inquiries in the Causes of Saints, December 16, 2006, AAS 99 (2007), 465-517.

${ }^{43}$ Carta de la 180 Comisión Permanente al Administrador Diocesano de La Rioja (August 21, 2018), accessed October 1, 2018, www.episcopado.org/contenidos.
} 
available on https://press.vatican.va/content/salastampa/en/bollettino/pubblico/2017/07/11/ 170711a.html.

CONGREgATION FOR THE CAUSES OF SAINTS. Normae servandae in inquisitionibus ab Episcopis faciendis [Norms to be observed in inquiries made by bishops in the causes of saints], February 7, 1983. AAS 75 (1983), 396-403. English translation available on http://www.causesanti.va/ content/causadeisanti/it/documenti/normae-servandae_en.html.

CONGREgation FOR THE CAUSES OF SAINTS. Sanctorum Mater. Istruzione per lo svogimento delle Inchieste diocesane o eparchiali nelle Cause dei Santi [Instruction "Sanctorum Mater" For Conducting Diocesan or Eparchial Inquiries in the Causes of Saints], December 16, 2006. AAS 99 (2007), 465-517. English translation available on http://www.causesanti.va/ content/causadeisanti/it/documenti/sanctorum-mater_en.html.

CONGREgation FOR THE CAuses of SAINTS. Norme sull' amministrazione dei beni delle cause di beatificazione e canonizzazione, March 10, 2016. AAS 108 (2016), 495-98. No English translation available.

Congregation For the CAuSES OF SAINTS. Regolamento della Consulta Medica della Congregazione delle Cause dei Santi [Regulation of the Medical Board of the Congregation for the Causes of Saints], September 23, 2016. AAS 108 (2016): 1004-9. English translation available on https://press.vatican.va/content/salastampa/en/bollettino/pubblico/2016/09/23/160923a.html.

Congregation for the CAuses of SAints. Le Reliquie nella Chiesa: Autenticità e Conservazione [Relics in the Church: Authenticity and Preservation]. Bollettino, December 16, 2017. English translation available on http://www.vatican.va/roman_curia/congregations/csaints/ documents/rc_con_csaints_doc_20171208_istruzione-reliquie_en.html.

Decree No. 11.715, September 20, 1933. Boletín Oficial, April 5, 1934. Accessed October 1, 2018. http://www.saij.gob.ar/11715-nacional-creacion-diocesis-lns0002516-1933-09-20/12345 67890abc-defg-g61-52000scanyel.

\section{CASE LaW}

Federal Oral Court of La Rioja, National Judicial Branch. Case no. 97000411/2012, "Causa lesa humanidad 'Monseñor Angelelli'.” Accessed October 1, 2018. www.cij.gov.ar/nota-14019Lesa-humanidad-difunden-fallo-que-conden-a-los-dos-acusados-en-el-juicio-por-el-homicidio-delobispo-Angelelli.html.

\section{LITERATURE}

"A la Iglesia argentina le falta verbalizar la dictatura." Accessed September 7, 2018. www.lastampa.it/2017/03/08/vaticaninsider/a-la-glesia-argentina-le-falta-verbalizar-la-dictatura.

BAR, Wiesław. "O Biskupie niewygodnym dla rządzących.” In Gaudium in litteris, edited by Stanisław Janeczek, Wanda Bajor, and Michał Maciołek, 489-99. Lublin: Wydawnictwo KUL, 2009.

BAR, Wiesław. Sendero Luminoso - prześladowca. Lublin: Redakcja Wydawnictw KUL, 1999.

BAR, Wiesław. Sprawy kanonizacyjne Męczenników XX wieku. Studium nad jurysprudencja Kongregacji. Lublin: Wydawnictwo KUL, 2003.

BAR, Wiesław. "Sprawy kanonizacyjne za pontyfikatu papieża Franciszka." In Prawo i praktyka kanonizacyjna za pontyfikatu papieża Franciszka, edited by Lidia Fiejdasz-Buczek, 17-22. Lublin: Wydawnictwo KUL, 2018 [in print]. 
Baronetto, Luis M. Vida y Martirio de Mons. Angelelli Obispo de la Iglesia Católica. 2nd ed. Córdoba: Ed. Tiempo Latinoamericano, 2006.

BARTOLUCCI, Marcello. "La quarta via. Una nuova fattispecie nell'iter processuale delle canonizzazioni." L'Osservatore Romano, July 11, 2017. Accessed October 1, 2017. www.osservatore romano.va/it/news/la-quarta.

Beltramo, Álvarez A. "Más cerca de la beatificación: “Angelelli es nuestro'." La Stampa, May 16, 2018. Accessed September 7, 2018. www.lastampa.it/2018/05/16/vaticaninsider/mscerca-de-la-beatificacion-angelelli-es-nuestro.

CArrizo, Gastón. "Recordan al laico Wenceslao Perdernera en Sañogasta.” El Diario Chilecito, July 27, 2015, p. 1.

Carta de la 180 Comisión Permanente al Administrador Diocesano de La Rioja (August 21, 2018). Accessed October 1, 2018. www.episcopado.org/contenidos.

Cоцомво, Marcelo D. "Consideraciones sobre manifestaciones periodísticas agraviantes." Circ. Nro. 31/2018. Accessed October 21, 2018. http://www.episcopado.org/contenidos.php?id $=1766 \&$ tipo $=$ unica.

Colombo, Marcelo D. "Conclusión de la instrucción diocesana de la causa de canonización de Mons. Angelelli.” Circ. Nro. 36/2016. Accessed September 7, 2016. https://diocesisdelarioja. wordpress.com/2016/09/07/ conclusion-de-la-instruccion-diocesana-de-la-causa-de-canonizacionde-mons-angelelli.

Colombo, Marcelo D. "Reconocimiento del Martirio de Mons. Angelelli, los padres Murias y Longueville y el laico Wenceslao Pedernera." Circ. Nro. 24/2018, June 8, 2018. Accessed October 1, 2018. https://diocesisdelarioja.wordpress.com/2018/06/08/1272.

National Commission on the Disappearance of Persons. Nunca más. Informe... Buenos Aires: Eudeba, 1984.

"El primer de beato de la 'era Francisco' podría ser un cura asesinado por la dictadura argentina." Accessed October 1, 2018. https://www.periodistadigital.com/religion/america/2013/03/19/elprimer-beato-de-la-era-francisco-podria-ser-un-cura-asesinado-por-la-dictadura-argentina.shtml.

"En el camino de la declaración de santidad." Accessed October 1, 2018. www.pagina12. com.ar/120366-en-el-camino-de-santidad.

FRANCIS. "Niestrudzona pracownica miłosierdzia. Homilia (September 4, 2016).” L'Osservatore Romano, Polish ed. 9 (2016): 9-10.

"Gabriel Longueville." Accessed October 1, 2018. http://diocesisdelarioja.files.wordpress.com/ 2016/07/04-gabriel-lonfueville.pdf.

Gravet, Juan J. "Martires de la Iglesia en Argentina. Wenceslao Pedernera (39 años)." Accessed October 10, 2018. http:// martiresargentinos.blogspot.com/2012/07/wenceslao-pederneralaico.html.

"Homilía del Cardenal Mons. Jorge M. Bergoglio en ocasión del 30 Aniversario del fallecimiento de Mons. Enrique Angelelli-Catedra de La Rioja.” Accessed October 20, 2018. www.arzbaires. org.ar/ inicio/ homiliasbergoglio.html.

Las Cinco Conferencias Generals del Episcopado Latinoamericano. Bogotá: CELAM, 2014.

LuPPI, Hilda S. "Un futuro santo y su paso en las villas de J.L. Suárez." Accessed October 1, 2018. http://villasweb.org/ 2016/02/24/un-futuro-santo-y-su-paso-en-las-villas-de-j-1-suarez.

MAGISTER, Sandro. "El paso doble del Papa argentino." Accessed August 1, 2017. http://chiesa. espresso.repubblica.it/ articolo/1351008. 
MontesinOS, Vicente. “¿Puede alguien explicarme la beatificación de Monseñor Enrique Angelleli?” Accessed September 7, 2018. http://infovaticana.com/blogs/adoracion-y-liberacion/puede-alguien-explicarme-la-beatificacion-de-monsenor-enrique-angelelli.

Nazareno Pastrone, Pablo. "Mons. Enrique Angelelli, testigo de la Fe." Revista Teología 42, no. 118 (2015): 49-65.

Oliberti, Luis O., and Pablo N. Pastrone. Enrique Angelelli, obispo de la Rioja: a imagen de Buen Pastor. Buenos Aires: Ed. Guadalupe Agape Libros, 2016.

"Papa quiere canonizar a seis religiosos argentinos asesinados por militares." Accessed September 7, 2018. www.elobservador.com.uy/nota/papa-/quiere-canonizar-a-seis-religiosos-argentinosasesinados-por-militares.

Pastor y Profeta. Mensajes de Monseñor Angelelli. Buenos Aires: Ed. Claretiana, 1986.

PIETRZAK, Andrzej. Opcja na rzecz ubogich znakiem wiarygodności Kościoła. Pieniężno: Referat Misyjny Seminarium Duchownego Werbistów, 2002.

"Quién fue el laico asesinado en Sañogasta que el Vaticano analiza canonizar." Accessed October 1, 2018. http://www. elfederal online.com/2017/03/09/quien-fue-el-laico-asesinado-en-sanogasta-que-el-vaticano-analiza-canonizar.

ReHIN, Domingo A. Memoria de un Testigo: testimonio de la vida de fray Carlos de Dios Murias. Buenos Aires: Misiones Franciscanas Conventuales, 2005.

Scavo, Nello. "Braccato dai lupi per le vie di Buenos Aires. L'incontro tra Bergoglio e il vescovo di La Rioja negli anni della dittatura (October 14, 2014).” Accessed October 1, 2018. www.osservatoreromano.va/it/news/ braccato-dai-lupi-le-vie-di-baires.

Tomaszewski, Jarosław. "Konferencja Episkopatów Ameryki Łacińskiej, Las Cinco Conferencias Generales del Episcopado Latinoamericano." Roczniki Teologi Katolickiej 14, no. 2 (2015): 171-74.

"Una beatificación de tono político-ideológico." Accessed September 7, 2018. www.lanacion.com. ar/2157470-una-beatificacion-de-tono-politico-ideologico.

ZAMBELli, Cristoforo M. "Relazione del postulatore generale (November 20, 2000)." Accessed October 1, 2018. http://www.ofmconv. org/capgen01/reg-Postulator-IT.htm.

Zanin, Gabriel. "XXII Aniversario de la muerte de fray Carlos De Dios Murias." Accessed October 11, 2018. www.ofmconv.org/ x/Murias-sp.htm.

\section{FROM AN INCONVENIENT BISHOP TO THE INCOVENIENT DECISION TO RECOGNIZE HIM AS A MARTYR}

\section{Summary}

The title suggests that this article will continue on the subject addressed 10 years ago. The previous article was On a bishop who is inconvenient to those in power in Argentina-both the State and the Church. Despite the changes that have taken place in both spheres (the collapse of the military dictatorship after the 1983 elections, and changes in the episcopate and the judicial inquiry and elucidation of the circumstances of the murder of Bishop Angelelli), some people are denying Pope Francis' decision to recognise the martyrdom of the bishop and his collaborators (June 8, 2018). They see this beatification as inconvenient.

The author of the presented study challenges these arguments, both from the canon-law perspective and in light of canonization practice. Due to the passage of time (the martyrs died in the 
Diocese of La Rioja in 1976) and the geographical separation (South America), he first provides their short biographies. Due to numerous untrue data and overinterpretations disseminated by the media as to the course of the beatification processes at the diocesan phase, the also tries to bring order to the basic facts.

Key words: Enrique Angelelli; Carlos de Dios Murias; Gabriela Longueville; Wenceslao Pedernera; martyrs; beatification process; Bergoglio.

\section{Translated by Tomasz Patkowski}

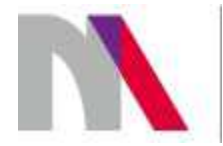

The preparation of the English version of Roczniki Nauk Prawnych (Annals of Iuridical Sciences) and its publication in electronic databases was financed under contract no. 836/PDUN/2018 from the resources of the Minister of Science and Higher Education for the popularization of science. 